\title{
INFLUENCE OF CHEMICAL COMPOSITION AND THE PROCESSING CONDITIONS ON STRUCTURE, THERMAL STABILITY AND MECHANICAL PROPERTIES OF RAPIDLY COOLED AI-TM-RE-BASED ALLOYS
}

\author{
V.K. Nosenko*, T.M. Mika, V.A. Mashira, O. Kandaurov, O.M. Semirga, V.P. Bevz \\ G.V. Kurdymov Institute for Metal Physics of the NAS of Ukraine, Kyiv, 03142, Ukraine \\ *e-mail:nosenko@imp.kiev.ua
}

\begin{abstract}
The results of $t$ studies are directed to development of new competitive amorphous and nanocrystalline alloys as well as to improvement of technology of their manufacturing. The physical and technological aspects of interrelations between the conditions for production of rapidly quenched alloys, formation of different structural and phase states, and their properties are discussed.

The influence of the chemical composition of alloys and the conditions of their quenching on the glassforming ability, phase composition, and the structure of the rapidly cooled specimens is investigated; the regularities of the effect of alloying elements concentration on the structural features of the $\mathrm{Al}_{75-}$ ${ }_{87}(\mathrm{Ni}, \mathrm{Co}, \mathrm{B} / \mathrm{Ga})_{8-20} \mathrm{Gd}_{1} \mathrm{Y}_{4}$ alloys obtained by superfast quenching from the liquid state are established. The thermal stability of the rapidly quenched ribbons with an amorphous structure is investigated and the temperature ranges of phase transformations at continuous heating and under isothermal conditions are found. The strength characteristics of the ribbons as a function of the content and nature of alloying elements as well as the melt cooling rate are determined. The methods of obtaining both Al-based bulk nanocrystalline composites with the shapes of rods and plates with thickness of $0.5-3.5 \mathrm{~mm}$ and metal matrix hardening coatings are worked out.

Keywords: aluminium, transition and rare earth metals, amorphous and nanocrystalline alloy, thermal stability, microhardness, metal matrix composite.
\end{abstract}

Received 02.07.2021; Received in revised form 03.08.2021; Accepted 15.08.2021

\section{Introduction}

Technologies that are based on the quenching from liquid state (QLS) methods allow at extreme non-equilibrium conditions to realize specific (including amorphous) structural phase states in metallic alloys which provide the unique combinations of strength, electrical, magnetic, corrosion, and other characteristics which are unattainable by using of the traditional metallurgical technologies.

It is well known in the scientific community that priority in this field which is naturally united the fundamental investigations with the effective material science and technological developments belongs to Ukrainian scientist Prof. I.S. Miroshnichenko which centenary was recently celebrated by the domestic scientific community. In the late 1950s, Prof. Miroshnichenko was one of the first researchers who developed the techniques of the ultrarapid quenching of metallic melts, obtained metallic glasses, and began the systematic studies of rapidly quenched materials [1]. His monograph "Quenching from liquid state" [2] written in the early 1980s remains very popular until now among the scientists working in this field.

The studies of Prof. Miroshnichenko focused on the analysis of the formation of supersaturated solid solutions in the alloy systems with eutectic and peritectic reactions [3]. In particular, he performed a detailed analysis of the structural features formed in binary Al-based alloys during melt quenching and showed for the first time that the degree of solid solution saturation depended on the rate of melt cooling. Prof. Miroshnichenko foresaw the effective perspectives of the materials obtained by the consolidation of the rapidly quenched lightweight Al-based powders or flakes. From the analysis of the publications [4-6] he concluded that the most important problem in the processing using hot pressing, extrusion techniques involving the heat treatments is the achievement of the highest strengthening of the consolidated products. In particular, for the supersaturated solid solutions formed in powders and flakes during melt quenching the highest strengthening occurs when the heat treatment results in the formation of the intermetallic phases particles with the optimal sizes, shapes, and distribution in the matrix. 
The Al-based alloys which combine low specific weight and high strength are widely used as structural materials in the industry, especially as lightweight components in aircraft and aerospace constructions [7]. The growing importance of environmental problems and energy saving, as well as technical progress, require new materials with enhanced levels of both mechanical properties and thermal stability. A solution to this problem may be realized by using new strengthening mechanisms because the traditional ones such as solid solution and dispersive hardening, grain refinement, deformation strengthening, and use of fibres result in Al-based alloys in the maximum value of yield stress of about $600 \mathrm{MPa}$ [7]. Subsequent progress in enhancement of strength of Al-based alloys was reached by obtaining materials with extremely disordered (amorphous), quasiand nanocrystalline structures which formed in the course of melt quenching or by controlled crystallization of amorphous phases. Among these structures which are formed presumably in the Al-RE-TM the partially crystalline structures composed of $\mathrm{Al}$ nanocrystals embedded into the amorphous matrix have the highest level of strength equals $1560 \mathrm{MPa}[8]$.

Despite the high level of the strength of the Al-RE-TM alloys with amorphous and nanocomposite structures, their applications are limited by the low sizes of the glassy samples ( $\leq 1 \mathrm{~mm}$ in one dimension) [9] and the high cost of the RE metals. To resolve these problems in the present study the attention was focused on the preferable use of the TM.

The important characteristic of the alloys with both amorphous and nanocomposite structures are the temperature and time ranges of their exploitation without deterioration of their properties which depends on the alloy chemical composition and the conditions of their fabrication $[10,11]$. Their determination requires research of the dynamics and kinetics of structural and phase transformations at the heating of the samples with nonequilibrium structures. In these studies, the features of the nanocluster structure of the amorphous phase were accounted which in turn were related to the structure of the melts [12]. Thus, the aim of this work was studies of the influence of the alloying TM such as $\mathrm{Ni}$ as well as its partial replacement with $\mathrm{Co}$ on the structure of the rapidly quenched $\mathrm{Al}_{75-83}(\mathrm{Ni}, \mathrm{Co}, \mathrm{B})_{12-20} \mathrm{Gd}_{1} \mathrm{Y}_{4}$ alloys, the thermal stability of amorphous phases, changes of microhardness caused by nanophase composite formation as well as working out of methods of the casting of bulk rods and plates with nanocomposite structures and obtaining metal-matrix strengthening coatings.

\section{Experimental}

The studied $\mathrm{Al}_{75-83}(\mathrm{Ni}, \mathrm{Co}, \mathrm{Ga}, \mathrm{B})_{12-20} \mathrm{Gd}_{1} \mathrm{Y}_{4}$ may be divided in three groups: low-alloyed $\mathrm{Al}_{87}(\mathrm{Ni}, \mathrm{Ga})_{8} \mathrm{Gd}_{1} \mathrm{Y}_{4}$ containing 8 at.\% of $\mathrm{TM}$, medium-alloyed $\mathrm{Al}_{81-}$ ${ }_{83}(\mathrm{Ni}, \mathrm{Co})_{14-12} \mathrm{Gd}_{1} \mathrm{Y}_{4}$ containing $12-14$ at.\% TM and highly-alloyed alloys $\mathrm{Al}_{75} \mathrm{Ni}_{20} \mathrm{Gd}_{1} \mathrm{Y}_{4}$, $\mathrm{Al}_{75} \mathrm{Ni}_{16} \mathrm{Co}_{4} \mathrm{Gd}_{1} \mathrm{Y}_{4}, \mathrm{Al}_{75} \mathrm{Ni}_{16} \mathrm{Co}_{3} \mathrm{~B}_{1} \mathrm{Gd}_{1} \mathrm{Y}_{4}$ and $\mathrm{Al}_{75} \mathrm{Ni}_{18} \mathrm{Ga}_{2} \mathrm{Gd}_{1} \mathrm{Y}_{4}$.

Ingots of the alloys studied were prepared from pure components $(\mathrm{Al}-99.99 \mathrm{wt} . \%$, $\mathrm{Ni}, \mathrm{Co}, \mathrm{B}, \mathrm{Ga}, \mathrm{Gd}$ and $\mathrm{Y}$ with $\geq 99.95$ wt.\% purity) by electric arc melting in a purified Ar atmosphere. RE were introduced into alloy as the preliminary prepared master alloys with compositions $\mathrm{Al}_{3} \mathrm{Y}$ and $\mathrm{Al}_{3} \mathrm{Gd}$. Rapidly quenched ribbons $(30-60 \mu \mathrm{m}$ thick and 10 $\mathrm{mm}$ width) were produced by single roller melt-spinning technique in a helium atmosphere. The chemical composition of the as-prepared ribbons was controlled by $\mathrm{X}$ ray fluorescence analysis.

The structural characterization of the as-prepared and heat-treated ribbons was carried out by X-ray diffraction (XRD) employing monochromatic Mo K and filtered Co $\mathrm{K} \alpha$ radiations in a standard DRON-3M diffractometer. The average Al grain sizes in nanophase composites were estimated from the full width at half maximum of the Bragg 30 
reflections using the deconvoluted XRD patterns. The average size of nanocrystals $L$ $(=\lambda / B \cos (\theta)$ with $\lambda$ being the wavelength and $\theta$ the scattering angle) and the average nearest-neighbour distance, $R=0.615 \lambda / \sin (\theta)$ were calculated from the X-ray data [13].

The thermal stability and crystallization kinetics was studied at constant rate heating (5-40 K/min) conditions by differential scanning calorimetry (DSC 404 F1 NETZSCH). The characteristic temperatures corresponding to the onset crystallization ( $\left.T_{\text {ona }}\right)$ and to the maximum rates of crystallization stages $\left(T_{\mathrm{i}}\right)$ were determined from the DSC scans with an accuracy of $\pm 1 \mathrm{~K}$. These data were used for calculations of the activation energies of crystallization stages using the well-known the Kissinger method [13].

The microhardness $\left(H_{\mu}\right)$ measurements of the as-cast and heat-treated samples were performed using standard PMT-3 microhardness tester calibrated with a $\mathrm{NaCl}$ monocrystal. The measurements were carried out on the flat areas presumably contact surfaces of 15 specimens at a load of $0.49 \mathrm{~N}$ (50 gf) during $10 \mathrm{~s}$. The $H_{\mu}$ values for each specimen were determined by averaging of 10 indents with regular shape which gave the standard deviation of the data about $\pm 1.5 \%$.

\section{Results and discussion}

\subsection{Effect of the TM concentration on structure and thermal stability of $\mathrm{Al}_{95-x}(\mathrm{Ni}, \mathrm{Co} / \mathrm{Ga})_{x} \mathrm{Gd}_{1} \mathrm{Y}_{4}(x=8,14(12), 20)$ rapidly quenched samples}

As mentioned above, until now the majority of studies were devoted to investigations of relatively low-alloyed Al-TM-RE alloys containing 85-87 at.\% Al. These studies (e.g., $[11,15,16])$ showed that the alloys $\mathrm{Al}_{86-87}(\mathrm{Ni}, \mathrm{Co})_{8}(\mathrm{Gd}, \mathrm{Y})_{5-6}$ obtained by the melt-spinning processing have amorphous structure according to the XRD data. It should be noted that the profiles of the first diffuse broad halo at the XRD patterns have the 'shoulders' at large scattering angles side. The analysis showed that this shoulder corresponds to the average interatomic distance of Al-TM pair such indicating the presence of the clusters. Another feature of the diffraction patterns glasses with low concentrations of TM was the presence of 'pre-peaks' at relatively low scattering angles (about $10^{\circ}$ in $M o K_{\alpha}$ ). The interatomic distance estimated from the Ehrenfest relation corresponding to the pre-peak is about $0.53-0.56 \mathrm{~nm}$. As it has been shown in [17] the pre-peak is caused by formation of the Al-RE clusters in which rare earth atoms are not in direct contact.

At the same time, it has been established that amorphous phases may be obtained in the melt-spun samples of Al-based alloys with enhanced content of transition metals up to 15 at. $\%\left(\mathrm{Al}_{81} \mathrm{Ni}_{15} \mathrm{Y}_{4}\right.$ and $\left.\mathrm{Al}_{75} \mathrm{Ni}_{15} \mathrm{Y}_{10}\right)$ [18] and to 20 at.\% $\left(\mathrm{Al}_{75}(\mathrm{Ni}, \mathrm{Co}, \mathrm{B})_{20} \mathrm{Gd}_{1} \mathrm{Y}_{4}\right)$ [19]. In order to study the effects of the chemical compositions on the structure of the rapidly quenched samples a series of the melt-spun ribbons with thickness 35-45 $\mu \mathrm{m}$ from the number of the Al-based alloys listed in Table 1 was obtained in the present study. As can be seen from Fig. 1 XRD patterns of all samples did not contain any sign of crystallinity. In turn, the DSC scans of the samples are typical for metallic glasses crystallizing via several studies (Fig. 2).

Analysis of the main broad maximum profiles shows that the increase of TM content in the alloys investigated results in enhancement of intensity of the high angle shoulder (Fig. 1). It lends support the above suggestion that this shoulder caused out Al-TM atomic interactions. In contrast, the relative intensity of the pre-peaks has no systematic dependency on the changes in concentration. In general, the structural studies of the rapidly quenched samples show the clear tendency of the AlNiCoGdY melts to phase separation. 


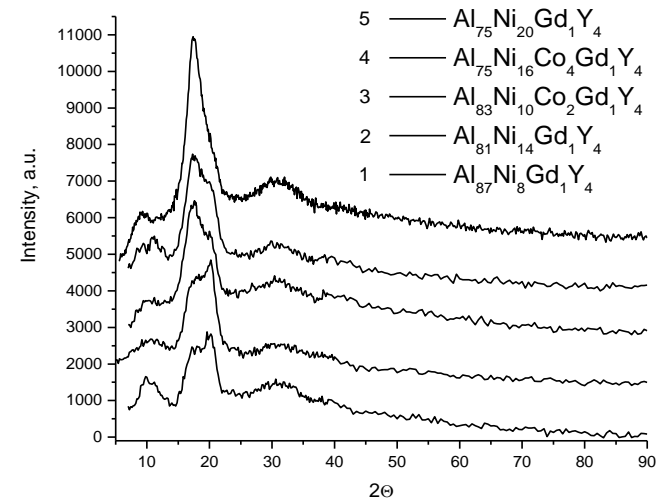

Fig. 1. X-ray diffraction patterns of the rapidly quenched ribbons of $\mathrm{Al}_{95-x}(\mathrm{Ni}, \mathrm{Co})_{x} \mathrm{Gd}_{1} \mathrm{Y}_{4}$ alloys $(x=8,14,20)$

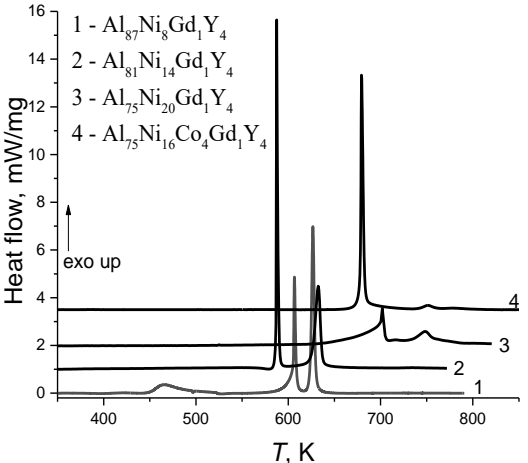

Fig. 2. DSC thermograms of Al95- $x$ $(\mathrm{Ni}, \mathrm{Co})_{x} \mathrm{Gd}_{1} \mathrm{Y}_{4}$ amorphous ribbons at heating rate of $20 \mathrm{~K} / \mathrm{min}$.

In order to estimate thermal stability of amorphous structure in the rapidly quenched samples the DSC thermograms were measured under constant rate heating. The results of these studies at $20 \mathrm{~K} / \mathrm{min}$ for the $\mathrm{Al}_{87} \mathrm{Ni}_{8} \mathrm{Gd}_{1} \mathrm{Y}_{4}, \mathrm{Al}_{81} \mathrm{Ni}_{14} \mathrm{Gd}_{1} \mathrm{Y}_{4}, \mathrm{Al}_{75} \mathrm{Ni}_{20} \mathrm{Gd}_{1} \mathrm{Y}_{4}$ and $\mathrm{Al}_{75} \mathrm{Ni}_{16} \mathrm{Co}_{4} \mathrm{Gd}_{1} \mathrm{Y}_{4}$ are presented in Fig. 2. From the DSC scans the values of the onset crystallization temperatures $\left(T_{\text {ons }}\right)$ as well as the temperastures corresponing to the maximum rates of transformations $\left(T_{\mathrm{p}}\right)$ at each crystallization stage were determined and listed in Table 1. As it is expected the increase of Ni content from 8 at.\% to 14 at.\% and to 20 at.\% results in enhancement of the onset crystallization temperature of amorphous phase from $463 \mathrm{~K}$ to $578 \mathrm{~K}$ and to $629 \mathrm{~K}$, respectively. The partial replacement of $\mathrm{Ni}$ with $\mathrm{Ga}$ and with Co in low-alloyed glasses leads to the decrease of $T_{\mathrm{ons}}$ while thermal stability of the highly-alloyed glasses increases (up to 658-669 K) due to additions of 4 at.\% Co and $\mathrm{B}$ and $\mathrm{Ga}$ at the expence of Ni (Table 1).

Table 1

Parameters of thermal stability of $\mathrm{Al}_{87} \mathrm{Ni}_{8} \mathrm{Gd}_{1} \mathrm{Y}_{4}, \mathrm{Al}{ }_{81-83}(\mathrm{Ni}, \mathrm{Co})_{14-12} \mathrm{Gd}_{1} \mathrm{Y}_{4}$ and $\mathrm{Al} \mathbf{7 5}_{5}(\mathrm{Ni}, \mathrm{Co}, \mathrm{B})_{20} \mathrm{Gd}_{1} \mathrm{Y}_{4}$ melt-spun ribbons

\begin{tabular}{|c|c|c|c|c|c|c|c|}
\hline Alloy composition & $\begin{array}{c}\text { Ribbon } \\
\text { thickness, } \mu \mathrm{m}\end{array}$ & $\begin{array}{c}T_{\mathrm{ons} 1}, \\
\mathrm{~K}\end{array}$ & $\begin{array}{c}T_{\mathrm{p} 1} \\
\mathrm{~K}\end{array}$ & $\begin{array}{c}T_{\text {ons } 2,} \\
\mathrm{~K}\end{array}$ & 2 & $\begin{array}{c}E_{\mathrm{al}}, \\
\mathrm{kJ} / \mathrm{mol}\end{array}$ & $\begin{array}{c}E_{\mathrm{a} 2}, \\
\mathrm{~kJ} / \mathrm{mol}\end{array}$ \\
\hline $\mathrm{Al}_{87} \mathrm{Ni}_{8} \mathrm{Gd}_{1} \mathrm{Y}_{4}$ & $45 \pm 5$ & 463 & 479 & 582 & 99 & $247 \pm 7$ & $350 \pm 2$ \\
\hline $\mathrm{Al}_{87} \mathrm{Ni}_{6} \mathrm{Ga}_{2} \mathrm{Gd}_{1} \mathrm{Y}_{4}$ & $45 \pm 5$ & 393 & 427 & 588 & 3 & $100 \pm 7$ & $355 \pm 3$ \\
\hline $\mathrm{Al}_{81} \mathrm{Ni}_{14} \mathrm{Gd}_{1} \mathrm{Y}_{4}$ & $35 \pm 5$ & 587 & 588 & 627 & 33 & $424 \pm 27$ & $207 \pm 8$ \\
\hline $\mathrm{Al}_{83} \mathrm{Ni}_{10} \mathrm{Co}_{2} \mathrm{Gd}_{1} \mathrm{Y}_{4}$ & $35 \pm 5$ & 583 & 584 & 637 & 41 & $473 \pm 6$ & $248 \pm 9$ \\
\hline $\mathrm{Al}_{75} \mathrm{Ni}_{20} \mathrm{Gd}_{1} \mathrm{Y}_{4}$ & $30 \pm 5$ & 629 & 702 & 711 & 6 & $449 \pm 34$ & $571 \pm 40$ \\
\hline $\mathrm{Al}_{75} \mathrm{Ni}_{18} \mathrm{Ga}_{2} \mathrm{Gd}_{1} \mathrm{Y}_{4}$ & $45 \pm 5$ & 636 & 637 & - & & $566 \pm 10$ & $576 \pm 32$ \\
\hline $\mathrm{Al}_{75} \mathrm{Ni}_{16} \mathrm{Co}_{4} \mathrm{Gd}_{1} \mathrm{Y}_{4}$ & $35 \pm 5$ & 669 & 679 & 742 & 751 & $614 \pm 5$ & $326 \pm 5$ \\
\hline $\mathrm{Al}_{75} \mathrm{Ni}_{16} \mathrm{Co}_{3} \mathrm{~B}_{1} \mathrm{Gd}_{1} \mathrm{Y}_{4}$ & $40 \pm 10$ & 658 & 666 & 755 & 756 & $622 \pm 64$ & $293 \pm 9$ \\
\hline
\end{tabular}

Structural analysis of the melt-spun samples heated up above the first crystallization stage showed that the main reason of the enhanced thermal stability of the medium- and highly-alloyed glasses was change of crystallization mechanism. While thermal stability of the low alloyed glasses is determined by the single-phase primary crystallization (formation of nanocrystals of pure $\mathrm{Al}+$ residual amorphous matrix) (Fig. 3a, pattern 1), simultaneous formation of several phases ( $\mathrm{Al}$ and $\mathrm{Al}$-rich binary and ternary intermetallic compounds) takes place at the first crystallization stage of the glasses with enhanced content of TM, Fig. 3(b-d), Table 2. 


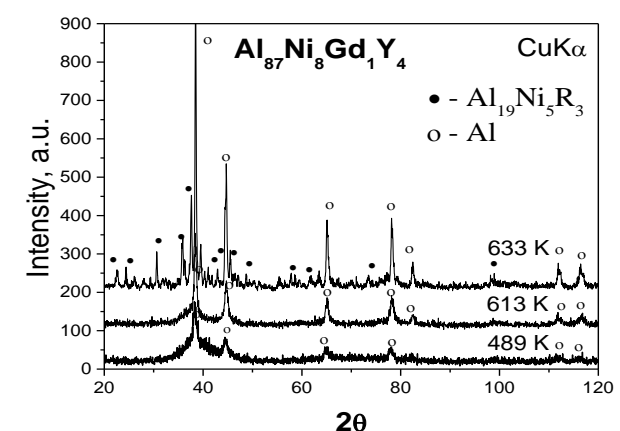

(a)

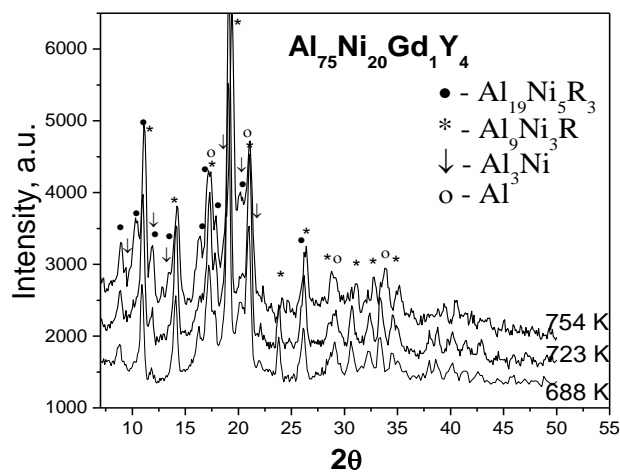

(c)

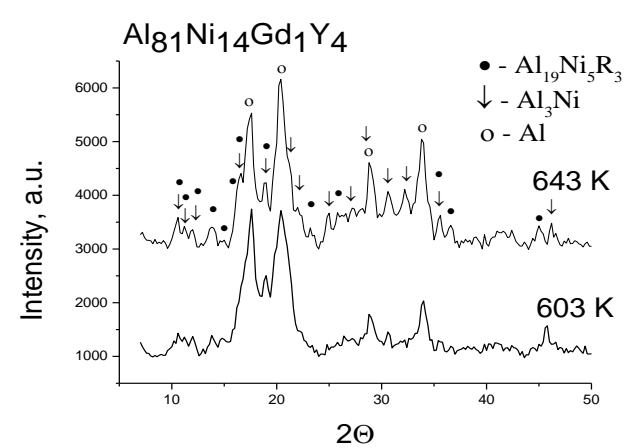

(b)

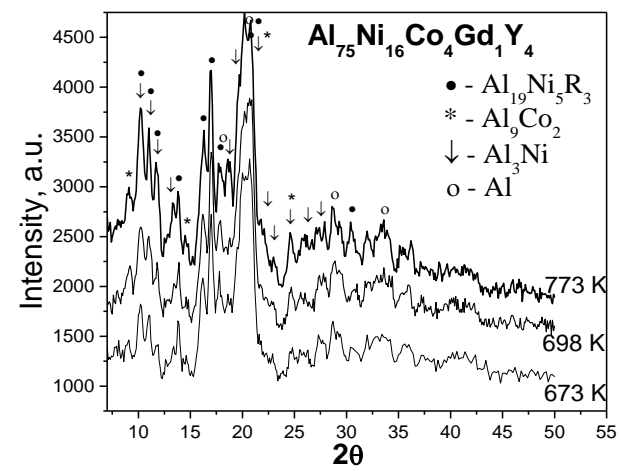

(d)

Fig. 3. X-ray diffraction patterns of the heat treated samples of low-alloyed $\left(\mathrm{Al}_{87} \mathrm{Ni}_{8} \mathrm{Gd}_{1} \mathrm{Y}_{4}\right)(\mathrm{a})$, medium-alloyed $\left(\mathrm{Al}_{81} \mathrm{Ni}_{14} \mathrm{Gd}_{1} \mathrm{Y}_{4}\right)(\mathrm{b})$ and highly-alloyed $\left(\mathrm{Al}_{75} \mathrm{Ni}_{20} \mathrm{Gd}_{1} \mathrm{Y}_{4}\right.$ and $\left.\mathrm{Al}_{75} \mathrm{Ni}_{16} \mathrm{Co}_{4} \mathrm{Gd}_{1} \mathrm{Y}_{4}\right)(\mathrm{c}, \mathrm{d})$ alloys.

The diffraction peaks of these phases are broadened indicating small (nanoscale) sizes of crystals. The absence of the amorphous halo on the diffraction patterns after the first crystallization stage of the medium and highly alloyed glasses supposes the eutectic crystallization mechanism. It follows from the $\mathrm{X}$-ray data that second and third peaks at the DSC scan of the $\mathrm{Al}_{87} \mathrm{Ni}_{8} \mathrm{Gd}_{1} \mathrm{Y}_{4}$ glass (Fig. 2) are caused by residual amorphous matrix crystallization (Fig. 3a), while second peaks at DSC scans of medium and highly alloyed glasses related to the crystalline phases transformations (grain growth of the phases formed at the first crystallization stage and increasing of the ternary intermetallic phases content, Table 2).

Quantitative phase composition of the melt spun ribbons at different stages of annealing

\begin{tabular}{|c|c|c|c|c|c|c|}
\hline \multirow{2}{*}{ Alloy composition } & \multirow{2}{*}{$T_{\text {ann., }} \mathrm{K}$} & \multicolumn{5}{|c|}{ Relative amount of the phase. } \\
\hline & & $\mathrm{Al}$ & $\mathrm{Al}_{3} \mathrm{Ni}$ & $\mathrm{Al}_{9} \mathrm{Co}_{2}$ & $\mathrm{Al}_{9} \mathrm{Ni}_{3} \mathrm{RE}$ & $\mathrm{Al}_{19} \mathrm{Ni}_{5} \mathrm{RE}_{3}$ \\
\hline \multirow{2}{*}{$\mathrm{Al}_{81} \mathrm{Ni}_{14} \mathrm{Gd}_{1} \mathrm{Y}_{4}$} & 603 & 26 & 17 & & & 57 \\
\hline & 643 & 12 & 14 & & & 74 \\
\hline \multirow{2}{*}{$\mathrm{Al}_{83} \mathrm{Ni}_{10} \mathrm{Co}_{2} \mathrm{Gd}_{1} \mathrm{Y}_{4}$} & 593 & 34 & 15 & 38 & & 13 \\
\hline & 663 & 34 & 16 & 25 & & 25 \\
\hline \multirow{3}{*}{$\mathrm{Al}_{75} \mathrm{Ni}_{20} \mathrm{Gd}_{1} \mathrm{Y}_{4}$} & 688 & 9 & 7 & & 39 & 45 \\
\hline & 723 & 5 & 8 & & 41 & 46 \\
\hline & 754 & 2 & 11 & & 25 & 62 \\
\hline \multirow{3}{*}{$\mathrm{Al}_{75} \mathrm{Ni}_{16} \mathrm{Co}_{4} \mathrm{Gd}_{1} \mathrm{Y}_{4}$} & 673 & 6 & 27 & 19 & & 48 \\
\hline & 698 & 3 & 11 & 34 & & 52 \\
\hline & 773 & 2 & 10 & 35 & & 52 \\
\hline \multirow{3}{*}{$\mathrm{Al}_{75} \mathrm{Ni}_{16} \mathrm{Co}_{3} \mathrm{~B}_{1} \mathrm{Gd}_{1} \mathrm{Y}_{4}$} & 658 & 5 & 30 & 20 & & 45 \\
\hline & 683 & 5 & 15 & 32 & & 48 \\
\hline & 823 & 3 & 18 & 23 & & 56 \\
\hline
\end{tabular}


It should be also noted here that first crystallization stage in the medium-alloyed glasses takes place in very low temperature range (scan 2 in Fig. 2) and there is a small endothermic effect before the crystallization peak (not shown). This minimum of heat flow is caused by the increase of the specific heat due the glass transition in amorphous phase which is not observed in both low- and highly alloyed glasses. Both the relatively enhanced the onset crystallization temperatures (583-587 K) and the activation energies of crystallization $(424-473 \mathrm{~K})$ of the $\mathrm{Al}_{81-83}(\mathrm{Ni}, \mathrm{Co})_{14-12} \mathrm{Gd}_{1} \mathrm{Y}_{4}$ compared with those of low alloyed glasses (Table 2) make the medium alloyed glasses attractive candidates for engineering applications.

The more detailed analysis of the phase compositions of the heat treated melt-spun samples was performed with using of the PowderCell 2.4 and FullProf2009 Software [20]. The results are summarized in Table 2. It is evident that the increase of the TM content results in the decrease of the fraction of $\mathrm{Al}$ nanocrystals and to complication of the phase composition. It is interesting to note that partial replacement of $\mathrm{Ni}$ with $\mathrm{Co}$ results in formation $\mathrm{Al}_{9} \mathrm{Co}_{2}$ phase and in suppression of formation of $\mathrm{Al}_{9} \mathrm{Ni}_{3} \mathrm{RE}$ ternary intermetallic compound. It indicates that the phase transformations in the melt-spun samples are governed mainly by interactions of the transition metals with $\mathrm{Al}$.

\subsection{Influence of transition metals content on microhardness of rapidly quenched samples}

As it is known the strength is the most important property of structural alloys. For its characterization the values of microhardness $\left(H_{\mu}\right)$ which are directly proportional to the yield strength [21] were used in the present study. The measurements showed that the increase of the TM content led to the enhancement of the $H_{\mu}$ from 2.6-2.8 GPa in the ascast glasses with 87 at.\% to $4.6-6.0 \mathrm{GPa}$ in the glasses with 75 at.\% (Table 3). It is interesting to note that partial replacement of $\mathrm{Ni}$ by $\mathrm{Ga}$ results in softening of the low alloyed glass and in hardening of the highly alloyed one. The opposite effects on hardness are observed due to partial replacement of $\mathrm{Ni}$ with $\mathrm{Co}$ in medium and highly alloyed glasses (Table 3).

Table 3

Microhardness of the as-cast and heat treated $(5 \mathrm{~min})$ ribbons

\begin{tabular}{|l|c|c|c|}
\hline \multicolumn{1}{|c|}{ Alloy } & Annealing temperature, $\mathrm{K}$ & $H_{\mu}, \mathrm{GPa}$ (as-cast) & $H_{\mu}, \mathrm{GPa}$ (annealed) \\
\hline $\mathrm{Al}_{87} \mathrm{Ni}_{8} \mathrm{Gd}_{1} \mathrm{Y}_{4}$ & 668 & $2,8 \pm 0,5$ & $4,5 \pm 1$ \\
\hline $\mathrm{Al}_{87} \mathrm{Ni}_{6} \mathrm{Ga}_{2} \mathrm{Gd}_{1} \mathrm{Y}_{4}$ & 610 & $2,6 \pm 0,4$ & $4,0 \pm 0,5$ \\
\hline $\mathrm{Al}_{81} \mathrm{Ni}_{14} \mathrm{Gd}_{1} \mathrm{Y}_{4}$ & 603 & $5,1 \pm 0,4$ & $7,7 \pm 1$ \\
\hline $\mathrm{Al}_{83} \mathrm{Ni}_{10} \mathrm{Co}_{2} \mathrm{Gd}_{1} \mathrm{Y}_{4}$ & 663 & $5,5 \pm 0,5$ & $7,6 \pm 1$ \\
\hline $\mathrm{Al}_{75} \mathrm{Ni}_{20} \mathrm{Gd}_{1} \mathrm{Y}_{4}$ & $800-820$ & $5,4 \pm 1$ & $9,7 \pm 1$ \\
\hline $\mathrm{Al}_{75} \mathrm{Ni}_{18} \mathrm{Ga}_{2} \mathrm{Gd}_{1} \mathrm{Y}_{4}$ & $633-673$ & $6,0 \pm 0,4$ & $9,5 \pm 0,7$ \\
\hline $\mathrm{Al}_{75} \mathrm{Ni}_{16} \mathrm{Co}_{4} \mathrm{Gd}_{1} \mathrm{Y}_{4}$ & 823 & $4,6 \pm 0,6$ & $9,5 \pm 1$ \\
\hline $\mathrm{Al}_{75} \mathrm{Ni}_{16} \mathrm{Co}_{4} \mathrm{~B}_{1} \mathrm{Gd}_{1} \mathrm{Y}_{4}$ & 773 & $5,0 \pm 0,8$ & $10 \pm 1$ \\
\hline
\end{tabular}

Formation of crystalline phases in amorphous glasses results in essential hardening (Table 3, Fig. 4) by from 50 to $100 \%$. In part, microhardness of the heat treated glasses is increased up to $10 \mathrm{GPa}$ which corresponds to the extremely high value of yield stress about $3 \mathrm{GPa}$ [21]. The main contribution into the increase of the hardness is caused by small sizes of crystals of $\mathrm{Al}$ and intermetallic compounds. The coarsening of the grain structure results in the decrease of hardness down to values of the as-cast samples (Fig. 4).

Thus, the very high values of microhardness found in the heat-treated samples with fine-grained structure of the medium- and highly alloyed Al-based glasses indicate that 
these alloys may be used as the basis for the development high-strength light-weight alloys with the properties superior to the commercial alloys. Priority of the authors in the field of development these alloys id protected by the Ukrainian patent [21].

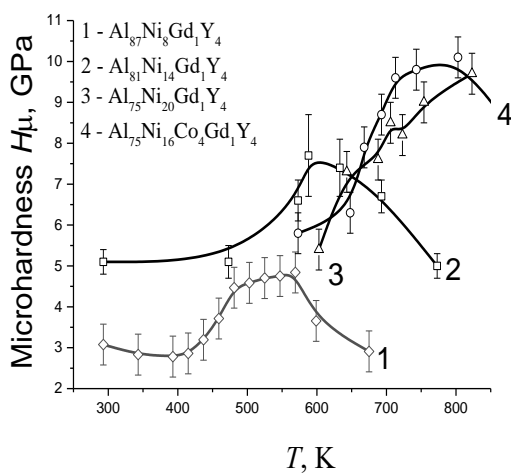

Fig. 4. Changes of microhardness of the meltspun $\quad \operatorname{Al}_{87-75}(\mathrm{TM})_{8-20}(\mathrm{RE})_{5}$ ribbons on the annealing temperature for $5 \mathrm{~min}$.

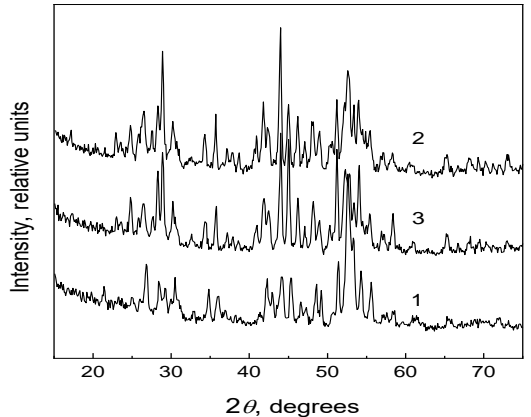

Fig. 5. XRD patterns of the plates of: 1) $\mathrm{Al}_{75} \mathrm{Ni}_{20} \mathrm{Gd}_{1} \mathrm{Y}_{4}$ alloy $1.8 \mathrm{~mm}$ thick $\left.(q=560 \mathrm{~K} / \mathrm{c}) ; 2\right)$ $\mathrm{Al}_{75} \mathrm{Ni}_{16} \mathrm{Co}_{4} \mathrm{Gd}_{1} \mathrm{Y}_{4}$ alloy $2.3 \mathrm{~mm}$ thick $\left.(q=440 \mathrm{~K} / \mathrm{c}) ; 3\right)$ $\mathrm{Al}_{75} \mathrm{Ni}_{16} \mathrm{Co}_{3} \mathrm{~B}_{1} \mathrm{Gd}_{1} \mathrm{Y}_{4}$ alloy $2.5 \mathrm{~mm}$ thick $(q=406 \mathrm{~K} / \mathrm{c})$.

Accounting these results the attempt to obtain bulk samples of highly alloyed alloys by ejection of melt into wedge-shape $\left((2.5-3.5) \times 5 \mathrm{~mm}^{2}\right.$ copper mold. It allows obtaining in single sample the set of structures formed at different cooling rates $(q)$ which were calculated from the empirical relationship [22] $q=10+989 / D$ where $D$ is thickness (in $\mathrm{mm}$ ) of the wedge. XRD studies showed that all plates had crystalline structure (Fig. 5) without any observable differences in the parts of samples with different thickness. Analysis of the XRD patterns revealed the multi-phase structure of the plates in which the the ternary $\mathrm{Al}_{19} \mathrm{Ni}_{5} \mathrm{RE}_{2}$ dominated. This phase with orthorhombic unit cell ( $a=0.4078$ $\mathrm{nm}, b=1.599 \mathrm{~nm}, c=2.698 \mathrm{~nm}$ ) is formed at the final stages of transformation of low alloyed amorphous alloys [11,23].

Table 4.

Microhardness of as-prepared and annealed bulk samples of AINiCoGaYGd alloys

\begin{tabular}{|l|c|c|}
\hline \multicolumn{1}{|c|}{ Alloy composition } & $\begin{array}{c}H_{\mu}, \mathrm{GPa} \\
\text { (as-prepared samples) }\end{array}$ & $\begin{array}{c}H_{\mu}, \mathrm{GPa} \\
\text { (bulk plate after annealing) }\end{array}$ \\
\hline $\mathrm{Al}_{75} \mathrm{Ni}_{20} \mathrm{Gd}_{1} \mathrm{Y}_{4}$ & $3,6 \pm 1$ & $3,91 \pm 0,4$ \\
\hline $\mathrm{Al}_{75} \mathrm{Ni}_{16} \mathrm{Co}_{4} \mathrm{Gd}_{1} \mathrm{Y}_{4}$ & $4,2 \pm 0,6$ & $4,72 \pm 0,3$ \\
\hline $\mathrm{Al}_{75} \mathrm{Ni}_{16} \mathrm{Co}_{3} \mathrm{~B}_{1} \mathrm{Gd}_{1} \mathrm{Y}_{4}$ & $3,9 \pm 0,8$ & $4,27 \pm 0,3$ \\
\hline $\mathrm{Al}_{75} \mathrm{Ni}_{18} \mathrm{Ga}_{2} \mathrm{Gd}_{1} \mathrm{Y}_{4}$ & $4,7 \pm 0,4$ & $5,3 \pm 0,5$ \\
\hline $\mathrm{Al}_{81} \mathrm{Ni}_{14} \mathrm{Gd}_{1} \mathrm{Y}_{4}$ & $4,3 \pm 0,4$ & $4,8 \pm 0,5$ \\
\hline $\mathrm{Al}_{83} \mathrm{Ni}_{10} \mathrm{Co}_{2} \mathrm{Gd}_{1} \mathrm{Y}_{4}$ & $4,4 \pm 0,5$ & $4,9 \pm 0,6$ \\
\hline
\end{tabular}

Microhardness of the rapidly solidified plates is in the range between 5.0 $\left(\mathrm{Al}_{75} \mathrm{Ni}_{16} \mathrm{Co}_{3} \mathrm{~B}_{1} \mathrm{Gd}_{1} \mathrm{Y}_{4}\right)$ and $6.0 \mathrm{GPa}\left(\mathrm{Al}_{75} \mathrm{Ni}_{18} \mathrm{Ga}_{2} \mathrm{Gd}_{1} \mathrm{Y}_{4}\right)($ Table 4), i.e. lower than that found in the glassy melt-spun ribbons with the same composition (Table 3). The most probable reason of this difference is relatively coarse grained structure of the plates (Fig. 6) which consists of at least three structural elements with different morphology. In contrast to the samples with amorphous structure heat treatment of the bulk plates does not appreciably change their hardness (Table 4).

In view that engineering applications of high-strength structural Al-based alloys require materials in bulk forms while maximum size of the cast billets with amorphous structure achieved until now is about $1 \mathrm{~mm}$, the most perspective way to realize the high 
level of mechanical properties of disordered and partially ordered (nanocrystalline) structures is consolidation of the rapid quenching products.

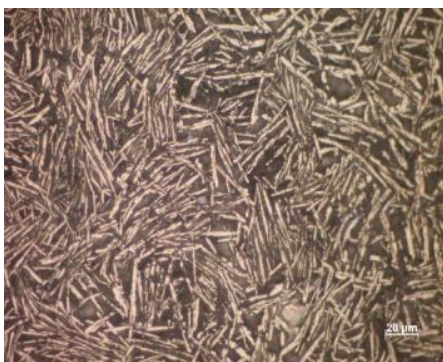

(a)

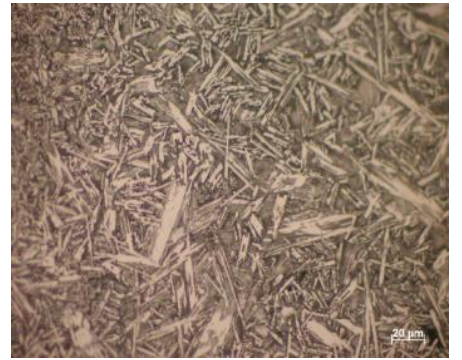

(b)

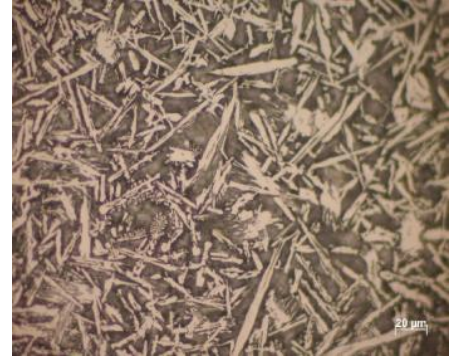

(c)

Fig. 6. Microstructure of $\mathrm{Al}_{75} \mathrm{Ni}_{20} \mathrm{Gd}_{1} \mathrm{Y}_{4}$ (a), $\mathrm{Al}_{75} \mathrm{Ni}_{16} \mathrm{Co}_{4} \mathrm{Gd}_{1} \mathrm{Y}_{4}$ (b) and $\mathrm{Al}_{75} \mathrm{Ni}_{16} \mathrm{Co}_{3} \mathrm{~B}_{1} \mathrm{Gd}_{1} \mathrm{Y}_{4}$ (c) as-prepared plates $(\times 500)$

\subsection{Recommendations concerning development and practical application of new nanocrystalline high-strength light-weight Al-based alloys}

In the frames of these investigations the conclusion has been drawn that consolidation of rapidly quenched ribbons and flakes is required to obtain bulk billets with amorphous and nanocomposite structures. Because, the supercooled liquid region (the difference between the onset crystallization and glass transition temperatures) in amorphous Al based alloys is small $(\leq 20 \mathrm{~K}$ [9]) the thermomechanical processes in the course of consolidation will inevitably lead to crystallization. In fact, the temperatures required for full consolidation by extrusion [24-28], by spark plasma sintering [29, 30] or by forging [31] as a rule exceed $673 \mathrm{~K}$, and it results in formation of microstructures which consist of crystals of $\mathrm{Al}$ and $\mathrm{Al}(\mathrm{TM}, \mathrm{RE})$ intermetallic compounds. In the other hand, it is known from the literature [32-34] that maximum of microhardness is observed in the samples with nanocomposite structure (nanocrystals of $\mathrm{Al}$ embedded in the residual amorphous matrix), while formation of the intermetallic compounds results in softening. In order to achieve the maximum density at lower temperatures and retaining of nanocomposite structure in Al-based alloys the 1 methods of severe plastic deformation (SPD) were successfully applied [35, 36, 37]. The experiments carried out allowed to obtain bulk nanostructured samples of $\mathrm{Al}_{86} \mathrm{Ni}_{6} \mathrm{Co}_{2} \mathrm{Gd}_{6}$ alloy at $523 \mathrm{~K}$ using twist extrusion [37], $\mathrm{Al}_{89} \mathrm{Gd}_{7} \mathrm{Ni}_{2} \mathrm{Fe}_{1}$ alloy at $473 \mathrm{~K}$ by equal channel angle extrusion [36] and $\mathrm{Al}_{90} \mathrm{Fe}_{5} \mathrm{Nd}_{5}$ alloy even at room temperature using high pressure torsion [35].

As it was shown above, the nanoscale crystals of intermetallic compounds which formed simultaneously with $\mathrm{Al}$ nanocrystals may contribute to hardening of nanophase composites. The comparison of the thermal stability of the investigated alloys at isothermal annealing with temperatures required for full consolidation by methods of equal channel angle extrusion (473 K [36]) and by twist extrusion (523 K [37]) shows that these SPD techniques allow to retain the nanocomposite structure in the majority of new amorphous alloys.

One of the new approaches for fabrication of light-weight high-strength ductile bulk alloys is using of amorphous Al-based alloys as reinforcement particles in metal-matrix composites (MMC) [38]. For example, addition of 10 and $20 \%$ of amorphous $\mathrm{Al}_{85} \mathrm{Ni}_{10} \mathrm{La}_{5}$ powder to cryomilled $5083 \mathrm{Al}$ results in enhancement of the ultimate strength of the extruded bars from 681 to 813 and $906 \mathrm{MPa}$, respectively [38]. The extruded bars had limited fracture deformation (3.3 and $2.4 \%$ in MMC with 10 and 20\%, respectively), however, subsequent swaging of $10 \% \mathrm{MMC}$ led to essential enlargement of plasticity at compression (up to 22.5\%) combined with relatively high yield stress (729 MPa) [39]. Another way to increase of plasticity of MMC was proposed in [40]. In this study the 
ductile nanocrystalline powder of $\mathrm{Al}_{94} \mathrm{Fe}_{4} \mathrm{Mo}_{0,6} \mathrm{~V}_{1,1} \mathrm{Zr}_{0,3}$ alloy was added to high strength amorphous $\mathrm{Al}_{84} \mathrm{Ni}_{10} \mathrm{Ce}_{6}$ powder and the fully consolidated bulk samples were obtained by forging at 648-773 K. It was established that the MMC samples consolidated at 648-673 $\mathrm{K}$ had the high compression strength $(1.2 \mathrm{GPa})$ and plasticity $1 \%$, while the bulk sample consolidated at $723 \mathrm{~K}$ had very high strength $(1.34 \mathrm{GPa})$ without ductility.

We have assumed that the increase of the volume fraction of ductile material will allow to obtain MMC with high strength and acceptable level of plasticity. For this purpose the alloys which retain the high strength in the fully crystalline state such as $\mathrm{Al}_{83-75}(\mathrm{Ni}, \mathrm{Co})_{12-20} \mathrm{Gd}_{1} \mathrm{Y}_{4}$ are available. For fabrication $\mathrm{MMC}$ we used the embrittled amorphous ribbons and flakes of medium $\left(\mathrm{Al}_{81} \mathrm{Ni}_{14} \mathrm{Gd}_{1} \mathrm{Y}_{4}\right)$ and highly $\left(\mathrm{Al}_{75} \mathrm{Ni}_{20} \mathrm{Gd}_{1} \mathrm{Y}_{4}\right)$ alloyed alloys. Amorphous $\mathrm{Al}_{81} \mathrm{Ni}_{14} \mathrm{Gd}_{1} \mathrm{Y}_{4}$ ribbon was annealed at $663 \mathrm{~K}$ in an argon atmosphere, milled and separated into $10-60 \mu \mathrm{m}$ fractions. The hardness of annealed ribbon was $5.5 \mathrm{GPa}$. The powder was mixed with $1-20 \mu \mathrm{m}$ fraction of Al powder in the ratio to 3:7, respectively, and the mixture was used for fabrication of MMC as protective coating on the surface of the hypoeutectic soft AlSi alloy by the cold gas-dynamic spraying (https://reym.prom.ua/p739290046-apparat-gazodinamicheskogo-napyleniya. html). This technology used now for renewal of surface of products, hardening and for corrosion protection allowed forming coatings as Al-based MMC (Figs. 7, 8). The formation of the MMC was performed at relatively low temperatures at which nanoscale microstructure of reinforcing $\mathrm{Al}_{81} \mathrm{Ni}_{14} \mathrm{Gd}_{1} \mathrm{Y}_{4}$ powder was retained.

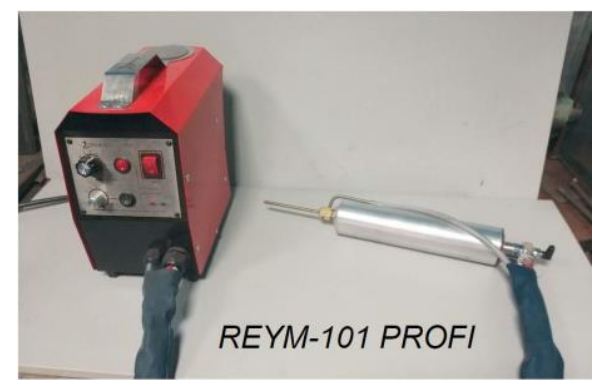

Fig. 7. General view of the device for the cold gas-dynamic spraying.

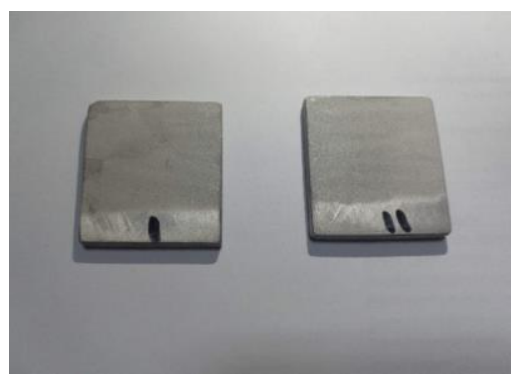

Fig. 8. The AlSi templates with the protective coatings.

The coatings are dense because they form as a result of precipitation of the mixture of powder moving with supersonic speed $(500 \ldots 1000 \mathrm{~m} / \mathrm{s})$. The microhardness of the coating $\leq 40 \mu \mathrm{m}$ was $2.7 \mathrm{GPa}$, i.e. by about 2.5 times higher than $H_{\mu}$ of AlSi substrate $(1.1 \mathrm{GPa})$. The reached values of MMC microhardness are not record, partially due to using of fully crystallized $\mathrm{Al}_{81} \mathrm{Ni}_{14} \mathrm{Gd}_{1} \mathrm{Y}_{4}$ powder but not the only embrittled. In general, gas-dynamic impact on nanostructure of reinforcing powder, possible diffusion of its components into matrix AlSi material, structure and phase composition of MMC were not investigated in this study. Nevertheless, the analysis and preliminary experiments carried out for fabrication nanostructured MMC on metallic surfaces indicate that the treatment which unites the nanocrystallization of amorphous phase and consolidation processes is a perspective way for production of bulk light-weight and high strength Al-based materials.

\section{Conclusions}

It is established that the increase of the TM content from 8 to 20 at.\% essentially enhances thermal stability of rapidly quenched amorphous $\mathrm{Al}_{87-75}(\mathrm{Ni}, \mathrm{Co})_{8-20}(\mathrm{Gd}, \mathrm{Y})_{5}$ alloys which is caused out by the change of mechanism of the first crystallization stage from the single phase (formation of $\mathrm{Al}$ nanocrystals in the $\mathrm{Al}_{87} \mathrm{Ni}_{8} \mathrm{Gd}_{1} \mathrm{Y}_{4}$ alloy) to the multi phase one (simultaneous formation of nanoscale crystals of $\mathrm{Al}$ and intermetallic compounds in the $\mathrm{Al}_{75} \mathrm{Ni}_{16} \mathrm{Co}_{4} \mathrm{Gd}_{1} \mathrm{Y}_{4}$ alloy). 
The specific feature of the DSC scans of the firstly prepared in this study medium alloyed $\mathrm{Al}_{81} \mathrm{Ni}_{14} \mathrm{Gd}_{1} \mathrm{Y}_{4}$ and $\mathrm{Al}_{81} \mathrm{Ni}_{10} \mathrm{Co}_{4} \mathrm{Gd}_{1} \mathrm{Y}_{4}$ alloys is the presence of the glass transition and sharp first crystallization peak such indicating the increase of the rate of crystallization in the range $(583-587 \mathrm{~K})$ above $T_{\text {ons }}$. The activation energy of the first crystallization stage in the $\mathrm{Al}_{81-83}(\mathrm{Ni}, \mathrm{Co})_{14-12} \mathrm{Gd}_{1} \mathrm{Y}_{4}$ amorphous alloys are relatively high $(424-473 \mathrm{~kJ} / \mathrm{mol})$ and even exceed that for the $\mathrm{Al}_{75} \mathrm{Ni}_{20} \mathrm{Gd}_{1} \mathrm{Y}_{4}$ glass.

The $\mathrm{Al}_{81}(\mathrm{Ni}, \mathrm{Co}){ }_{14} \mathrm{Gd}_{1} \mathrm{Y}_{4}$ and $\mathrm{Al}_{75}(\mathrm{Ni}, \mathrm{Co}){ }_{20} \mathrm{Gd}_{1} \mathrm{Y}_{4}$ alloys possess essentially enhanced microhardness (by 50\% and $100 \%$, respectively) in comparison with $H_{\mu}$ low alloyed $\mathrm{Al}_{87} \mathrm{Ni}_{8} \mathrm{Gd}_{1} \mathrm{Y}_{4}$ glass in the as-prepared and in heat-treated states. In new medium alloyed glasses formation of nanocomposite structure results in relatively small increase in microhardness from 5.1 - 5.4 to 7.6-7.7 GPa. In the highly alloyed glasses the highest microhardness $(9,7 \mathrm{GPa})$ is achieved after the second crystallization stage. Coarsening of crystalline structures at final stages of transformations results in the essential decrease of microhardness.

The presented results allow to formulate the following recommendations concerning the development of practical application of new nanocrystalline high-strength Al-based alloys (composites):

- for obtaining of bulk rod and plates consolidated from amorphous melt-spun ribbons the alloys $\mathrm{Al}_{86} \mathrm{Ni}_{6} \mathrm{Co}_{2} \mathrm{Gd}_{3} \mathrm{Y}_{2} \mathrm{~Tb}_{1}$ and $\mathrm{Al}_{86}(\mathrm{Ni}, \mathrm{Co})_{8}(\mathrm{Gd}, \mathrm{Y})_{6}$ [41] may be efficiently used due to their high glass forming ability, thermal stability and hardness;

- for obtaining of metal-matrix composites by the cold gas-dynamic spraying on surfaces structural light alloys the medium- and highly-alloyed $\mathrm{Al}_{81-75}(\mathrm{Ni}, \mathrm{Co})_{14-20} \mathrm{Gd}_{1} \mathrm{Y}_{4}$ alloys may be used due to their high microhardness in the nanocrystalline states and high stability of the properties in wide temperature ranges;

- the proposed method for fabrication of the Al-based nanostructured metal-matrix composites with high density is energy saving and may be used for development of new metal-polymer composites.

\section{Acknowledgments}

The work was performed within the framework of the Targeted Comprehensive Program of Basic Research of the National Academy of Sciences of Ukraine "Fundamental Problems of Creating New Nanomaterials and Nanotechnologies" under the project 2015-2019. (№ state registration 0115U005047)

\section{References}

1. Miroshnichenko, I.S. Ustanovka dlya kristallizatsii splavov s bol'shoi skorost'yu okhlazdeniya / I.S. Miroshnichenko, I.V. Sally // Zavodskaya laboratoria, 1959. - Vol. 25, No 1. - p 1398 - 1399.

2. Miroshnichenko, I.S. Zakalka iz zhidkogo sostoyaniya / I.S. Miroshnichenko. Moscow: Metalurgiya. - 1982. -168 p.

3. Miroshnichenko, I.S. Rost i nesovershenstva metallicheskih kristalov / I.S. Miroshnichenko. - Kyiv:Naukova dumka. - 1966, p.320-325.

4. Yakunin, A.A. Vliyanie zakalki iz rasplava i termicheskoy obrabotki na structuru i svoistva splavov aluminiy-marganec / A.A Yakunin., I.I. Osipov, V.I. Tkach, A.B. Lysenko // FMM. - 1997. - V43, No 1. - p. 140-144.

5. Elagin, V.I. Legirovaniye deformiruyemykh alyuminiyevykh splavov perekhodnymi metallami / V.I. Elagin. - Moscow: Metalurgiya. - 1975. - 247 p.

6. Fridlyander I.N. Poroshkovyye splavy alyuminiya $\mathrm{s}$ malorastvorimymi dobavkami / I.N. Fridlyander, O.A. Bryukhovets, M.G. Stepanova, O.A. Setyukov // Alyuminiyevyye splavy, No 5, Moscow, Metalurgiya, 1968, p. 226-230. 
7. Williams, J.C. Progress in structural materials for aerospace systems / J.C. Williams, E.A. Starke // Acta Mater. - 2003. - Vol. 51. - p. 5775-5799.

8. Inoue, A. Fabrication and mechanical properties of bulk amorphous, nanocrystalline, nanoquasicrystalline alloys in aluminum-based system / A. Inoue, H. Kimura // J. Light Met. - 2001. - Vol. 1. - p. 31-41.

9. Yang, B.J. Al-rich bulk metallic glasses with plasticity and ultrahigh specific strength / B.J Yang., J.H Yao., J. Zhang, H.W. Yang., J.O Wang., E. Ma // Scr. Mater. - 2009. - Vol. 61. - p. 423- 426.

10. Nosenko, V. K. Vliyaniye soderzhaniya ittriya na termicheskuyu ustoychivost i protsessy nanokristallizatsii amorfnykh splavov Al / V.K. Nosenko, Ye.A. Segida, A.A. Nazarenko, T.N. Moiseyeva, S.A. Kostyrya, E.A. Svirdova, V.I. Tkach. // "Nanosystemy, nanomaterialy, nanotekhnolohiyi”. - 2013. - Vol. 11, No 1. - p. 57-71.

11. Mika, T. Influence of $\mathrm{Gd}$ and $\mathrm{Fe}$ on crystallization of $\mathrm{Al}_{87} \mathrm{Y}_{5} \mathrm{Ni}_{8}$ amorphous alloy / T. Mika, M. Karolus, G. Haneczok, L. Bednarska, E. Łagiewka, B. Kotur // J. Non-Cryst. Solids. - 2008. - Vol 354. - p. 3099-3106.

12. Ladyanov, V.I., O vyazkosti stekloobrazuyushchikh rasplavov $\mathrm{Al}_{86}(\mathrm{Ni}, \mathrm{Co})_{8} \mathrm{Gd}_{4}(\mathrm{Y} / \mathrm{Tb})_{2}$ / V.I. Ladyanov, A.L. Beltyukov, S.G. Menshikova, V.V. Maslov, .V.K. Nosenko, V.A. Mashira // Metallofizika i noveyshiye tekhnologii. - 2005. - Vol. 27, No 5. - p. 687-696.

13. Gorelik, S.S. Rentgenograficheskiy i elektronno-opticheskiy analiz / Yu.A. Skakov, L.N. Rastorguyev. - Moscow: MISIS. - 1994.

14. Kissinger, H. E. Reaction kinetics in differential thermal analysis / H.E. Kissinger // Anal. Che. -1957. - Vol. 29. - p. 1702-1706.

15. Nosenko, V.K. Vliyaniye zameny nikelya kobal'tom na termicheskuyu ustoychivost' i mikrotverdost splavov $\mathrm{Al}_{86} \mathrm{Ni}_{8} \mathrm{Gd}_{6}$ i $\mathrm{Al}_{86} \mathrm{Ni}_{8} \mathrm{Y}_{6} \mathrm{~S}$ amorfnoy i nanokompozitnoy strukturoy / V.K. Nosenko, Ye.A. Segida, A.A. Nazarenko, T.N. Moiseyeva, S.A. Kostyrya, Ye.A. Svirdova, V.I. Tkach // Metallofiz, Noveishie Tekhnol. - 2015. - Vol. 37, No 1. - p. 49 - 65.

16. Nosenko, V.K. Vliyaniye soderzhaniya ittriya na termicheskuyu ustoychivost' i protsessy nanokristallizatsii amorfnykh splavov $\mathrm{Al}_{86} \mathrm{Ni}_{6} \mathrm{Co}_{2} \mathrm{Gd}_{6-\mathrm{x}} \mathrm{Y}_{\mathrm{x}}$ i $\mathrm{Al}_{86} \mathrm{Ni}_{2} \mathrm{Co}_{6} \mathrm{Gd}_{6-\mathrm{x}} \mathrm{Y}_{\mathrm{x}}$, / V.K. Nosenko, Ye.A. Segida, A.A. Nazarenko, T.N. Moiseyeva, S.A. Kostyrya, E.A. Svirdova // "Nanosystemy, nanomaterialy, nanotekhnolohiyi". - 2013. - Vol. 11, No 1. - p. 57 - 71.

17. Sabet-Sharghi, R. Formation, structure, and crystallization of Al-rich metallic glasses / R. Sabet-Sharghi, Z. Altounian, W.B. Muir // J. Appl. Phys. - 1994. - Vol. 75, No. 9. - p. 4438.

18. Styles, M.J. On the competition in phase formation during the crystallisation of Al-Ni-Y metallic glasses / M.J. Styles, W.W. Sun, D.R. East, J.A. Kimpton, M.A. Gibson, C.R. Hutchinson // Acta Materialia. - 2016. - Vol. 117. - p. 170 - 187.

19. Mika, T. Vplyv lehuvannya ta termoobrobky na mikrotverdist nanokrystalichnykh splaviv Al-Ni-Co-Y-Gd / T. Mika, A. Nazarenko, H. Zelinska, B. Kotur, V. Nosenko // NANSYS 2013, Kyiv, 2013, S. K12.

20. Rodriges-Carvajal, J An introduction to the program FullProf 2000 / J. Rodriges-Carvajal // Laboratoire Léon Brillouin. - 2001. - p. 139.

21. Nosenko, V.K. Vysokomitsnyy splav na osnovi alyuminiyu/ Nosenko V.K., Mika T.M., Nazarenko H.O., Tkach V.I., Lytvynenko Y.M. // Patent na vynakhid No 04560, MPK: C22C 21/00, C22C 45/00. Puplished: 10.02.2014

22. Inoue, A. Recent progress in bulk glassy alloys /A. Inoue, A. Takeuchi // Mater. Trans. - 2002. - Vol. 43, No 8. - P. 1892 - 1906.

23. Vasiliev, A.L. Phase stability and microstructure in devitrified Al-rich Al-Y-Ni / A.L. Vasiliev, M. Aindow, M.J. Blackburn, T.J. Watson // Intermetallics. - 2004. - Vol 12. - P. 349-362.

24. Kawamura, Y. Nanocrystalline aluminium bulk alloys with a high strength of $1420 \mathrm{MPa}$ produced by the consolidation of aluminium powders / Y. Kawamura, H. Mano, A. Inoue // Scripta Mater. - 2001. - Vol. 44, No 8-9/ - p. 1599 - 1604. 
25. Shi, X.L. Elevated temperature deformation behavior of nanostructured Al-Ni-Gd-Fe alloys / X.L. Shi, R.S. Mishra, T.J. Watson // Scripta Mater. - 2005. - Vol. 52. - p. 887 - 891.

26. Wang, Y. Ductility improvement in devitrified ultrafine-grained $\mathrm{Al}-4.0 \mathrm{Y}-4.0 \mathrm{Ni}-0.9 \mathrm{Co}$ alloy via hot rolling/Y. Wang, X.L. Shi, R.S. Mishra, T.J. Watson// Scr. Mater. - 2007. - Vol. 56. - p. 923-925.

27. El-Shabasy, A.B. High cycle fatigue behavior of a nanostructured composite produced via extrusion of amorphous $\mathrm{Al}_{89} \mathrm{Gd}_{7} \mathrm{Ni}_{3} \mathrm{Fe}_{1}$ alloy powders / A.B. El-Shabasy, H.A. Hassan, Y. Liu, D. Li, J.J. Lewandowski // Mater. Sci. Eng. A. - Vol. 513-514. - p. 202 - 207.

28. Surreddi, K.B. Crystallization behavior and consolidation of gas-atomized $\mathrm{Al}_{84} \mathrm{Gd}_{6} \mathrm{Ni}_{7} \mathrm{Co}_{3}$ glassy powder / K.B. Surreddi, S. Scudino, M. Sakaliyska, K.G. Prashanth, D.J. Sordelet, J. Eckert // J. Alloys Compds. - 2010. - Vol. 491 . - p. 137 - 142.

29. Sassaki, T.T. Bulk nanocrystalline Al85Ni10La5 alloy fabricated by spark plasma sintering of atomized amorphous powders / T.T. Sassaki, K. Hono., J. Vierke, M. Wollgarten, J. Banhart // Mater. Sci. Eng. A. - 2008. - Vol. 490. - p. 343 - 350.

30. Surreddi, K.B. Spark plasma sintering of gas atomized $\mathrm{Al}_{8} \mathrm{Ni}_{8} \mathrm{La} 5$ amorphous powder / K.B. Surreddi, S. Scudino, H.V. Nguyen, K. Nikolowski, M. Stoica, M. Sakaliyska, J.S. Kim, T. Gemming, J. Vierke, M. Wollgarten, J. Eckert// J. Phys.: Conf. Ser.-2009. - Vol. 144. - p. 012079 (1-5).

31. Noh, S.-J. Microstructure and compressive behavior of Al-base amorphous/nanocrystalline alloys fabricated by powder forging / S.-J. Noh, T.-K. Jung, D.-S. Lee, M.-S. Kim // Mater. Sci. Eng. A. - 2007. - Vol. 449-451. - p. 799 - 803.

32. Rizzi, P. Microhardness and devitrification studies of Al-TM-RE alloys / P. Rizzi, L. Battezzati. // J. Alloy Compd. - 2007. - Vol. 434-435. - p. 36 - 39.

33. Wollgarten, M. Influence of La on the crystallisation behaviour of amorphous $\mathrm{Al}_{94-\mathrm{x}} \mathrm{Ni}_{6} \mathrm{La}_{\mathrm{x}}$ alloys / M. Wollgarten, K.L. Sahoo, J. Haug, J. Banhart // Mater. Sci. Eng. A. - 2007. - Vol. 449-451.p. 1049-1051.

34. Choi, G.S. Ultrahigh tensile strength of amorphous Al-Ni-(Nd,Gd)-Fe alloys containing nanocrystalline Al particles / G.S. Choi, Y.H. Kim, H.K. Cho, A. Inoue, T. Masumoto // Scr. Metall. Mater. - 1995. - Vol. 33, No 8. - p. 1301 - 1306.

35. Yavari, A.R., Nanostructured bulk $\mathrm{Al}_{90} \mathrm{Fe}_{5} \mathrm{Nd}_{5}$ prepared by cold consolidation of gas atomized powder using severe plastic deformation / A.R. Yavari, W.J. Botta Fihlo, C.A.D. Rodrigues, C. Cardoso, R.Z. Valiev // Scripta Mater.. - 2002. - Vol. 46. - p. 711 - 716.

36. Senkov, O.N. Compaction of amorphous aluminum powder by direct extrusion and equal channel angular extrusion / O.N. Senkov, Senkova S.V., Scott J.M., Miracle D.B. // Mater. Sci. Eng. A. - 2005. Vol. 393. - p. 12 - 21.

37. Shpak, A.P. Nanostructured $\mathrm{Al}_{86} \mathrm{Gd}_{6} \mathrm{Ni}_{6} \mathrm{Co}_{2}$ bulk alloy produced by twist extrusion of amorphous melt-spun ribbons / A.P. Shpak, V.N. Varyukhin, V.I. Tkatch V.V. Maslov, Y.Y. Beygelzimer, S.G. Synkov, V.K. Nosenko, S.G. Rassolov // Mater. Sci. Eng. A. - 2006. - Vol. 425. - p. 172 - 177.

38. Miracle, D.B. Metal matrix composites - From science to technological significance / D.B. Miracle // Comp. Sci. Technol. - 2005. - Vol. 65. - p. 2526 - 2540.

39. Zhang, Zh. Synthesis of nanocrystalline aluminum matrix composites reinforced in situ devitrified Al-Ni-La amorphous particles / Zh. Zhang, B.Q. Han, D. Witkin, L. Ajdelsztajn, E.J. Lavernia // Scr. Mater. - 2006. - Vol. 54. - p. 869 - 874.

40. S.-J. Noh Microstructure and compressive behavior of Al-base amorphous/nanocrystalline alloys fabricated by powder forging / S.-J. Noh, T.-K. Jung, D.-S Lee, M.-S. Kim // Mater. Sci. Eng. A. - 2007. - Vol. 449-451. - p. 799 - 803.

41. Maslov, V.V. Vliyaniye legirovaniya na termicheskuyu ustoychivost' i mikrotverdost' amorfnykh splavov $\mathrm{Al}_{86}(\mathrm{Ni}, \mathrm{Co})_{8}(\mathrm{Gd}, \mathrm{Y}, \mathrm{Tb})_{6} /$ Maslov V.V., Nosenko V.K., Mashira V.A., Tkach V.I., Rassolov S.G., Popov V.V., Krysov V.I. // Metallofizika i noveyshiye tekhnologii. - 2005. - Vol. 27, No 7. - p. 937 - 948. 